\title{
BACK TO THE FUTURE? AIMS AND ENDS FOR FUTURE-ORIENTED SCIENCE EDUCATION POLICY - THE NEW ZEALAND CONTEXT
}

\author{
JANE GILBERT \\ Jane.Gilbert@aut.ac.nz \\ Auckland University of Technology
}

\begin{abstract}
Science and science education are a focus of high-level government policy settings in many countries. Greater public interest in and knowledge of science is seen as being an important prerequisite for economic growth and social development in the Knowledge Age. In this article, I argue that current policy approaches are misguided and potentially harmful - for science, for education, and for future social development. Using specific examples from the New Zealand context, I argue that, because these policies are based on widely held but limited views of first, education, and second, science, they effectively colonise, rather than expand, the possibilities for our future. Drawing on ideas from educational thinkers of the past, such as John Dewey and Alfred North Whitehead, and ideas from contemporary futures thinkers, I put forward for consideration three very different scenarios for science education's future aims and ends.
\end{abstract}

Keywords: science education; science policy; innovation policy; future-focused education

\section{Introduction}

Science and science education are currently a strong focus of high-level government policy settings in many countries. In the New Zealand context, the purpose of this is to build New Zealand's capacity to be a "smart country where knowledge and innovation are at the heart of both economic growth and social development" (Gluckman, 2011, p. 1). In the policy context, greater public interest in - and knowledge of - science are seen as being crucial for future economic growth and social development, as are better linkages between science and innovation.

A key element in building this "smart" future, Gluckman argues, is a "forwardlooking" (p. vi) science education system. Meanwhile, in the education policy context, there is a lot of talk about "future-oriented" education: reconfiguring our education system to better prepare people for life and work in the twenty-first 
century. All this raises some questions that are not receiving much attention, but are, it seems to me, critical for the future of science and of education. For example:

1. In what ways do science and innovation overlap? Should they overlap?

2. If a key purpose of science is to contribute to innovation, what implications does this have for science education?

3. If we think school science should change, what might these changes look like?

4. Would these changes be "educative" (in the Deweyan sense)?

5. Would the changes support the development of a more "future-focused" education system?

This article explores these questions. It argues that key aspects of the current policy approach, because they rest on limited views of first, education, and second, science, are misguided and potentially harmful. Using examples from the New Zealand context, this article argues that these policies are restricting, not expanding, our future development possibilities.

The article has three sections. The first section outlines some key trends in recent science and science education policy, using the New Zealand context as an example. The second section sets out four very different reasons why these policies are not likely to produce a future-oriented science education system capable of turning out scientifically knowledgeable, innovation-ready citizens. The third section suggests three possible scenarios for science education's future aims and ends. The article's main focus is on high-level science - and science education policy: in particular, the ideas that appear to have underpinned recent policy developments. Although there are references to school science education, this is not a practice-oriented article. My concern is to unpack the - often unexamined ideas underpinning how we think about science education's purpose/s, and to look at how these ideas might need to be different in the $21^{\text {st }}$ century. A key aim is to examine the role science could play in supporting the development of genuinely "educative" experiences in a $21^{\text {st }}$ century education system.

\section{Contemporary Science and Science Education Policy - The Key Drivers}

In New Zealand and many other countries, the last few years have seen increased government emphasis on science and innovation as key drivers of our economic and social future. In New Zealand, the government ministries involved in science policy have undergone several major re-structuring exercises. In 2011, the former Ministry of Research, Science and Technology was replaced by a new Ministry of Science and Innovation (MSI), set up to support a "broader government focus on boosting science and innovation's contribution to economic growth." ${ }^{1}$ However, not long afterwards, in 2012, MSI was merged with the former Ministries of Economic Development, the Department of Labour, and the Department of Building and Housing to form a new "super-Ministry" known as the Ministry of Business, Innovation and Employment (MBIE). One of this new Ministry's 
purposes is to facilitate "closer connections between the scientists and innovators who can generate new ideas and solve problems, and the business people who can translate these ideas into income and jobs." ${ }^{2}$ Thus, over a period of about twenty years, the "old" notion of government science as an end in itself was disestablished. ${ }^{3}$ It was replaced by a new form of government science defined in terms of its links with innovation and, following from this, its capacity to generate business opportunities, employment and prosperity. Now, the government's role in relation to science is seen as being to "boost the number of knowledge-intensive, internationally-connected firms."

Another key development in New Zealand was the 2009 appointment of Sir Peter Gluckman as the inaugural Prime Minister's Chief Science Advisor. Science education was to be a key focus of this new role, and in 2011 Professor Gluckman, in a paper entitled Looking Ahead: Science Education in the 21st Century, wrote that "a forward-looking science education system is fundamental to our future success in an increasingly knowledge-based world" (Gluckman, 2011, p. vi). His paper's purpose was to explore how our science education system could be strengthened to support New Zealand's development as a "smart," innovative, knowledge-oriented country, capable of addressing the serious questions we will face in the future, and how we can engage and enthuse more young New Zealanders in science. It makes the case for the importance, in a participatory democracy, of all citizens having an understanding of scientific issues, arguing that "science literacy" should be a key focus of science education. For Gluckman, building overall levels of science literacy will not only grow our future scientists, but it will also grow our citizenship capabilities and create the conditions for innovation. According to him,

New Zealand must embrace science and technology and innovative thinking as a core strategy for its way ahead. [T]here is no doubt in my mind that a population better educated in science, whether or not they will actually use science in their career, is essential. (2011, p. 8)

The arguments made in Gluckman's science education paper were influential in the next set of developments in science research and education policy. They can be seen in the thinking behind the ten new National Science Challenges launched in 2012-13 and in MBIE's A Nation of Curious Minds initiative. ${ }^{5}$ These "Challenges" represent a major new approach to government science "investment." Eschewing "investigator-driven" research, they have been set up to bring scientists from different disciplines together to focus on a selection of the many highly complex and intractable, but pressing issues New Zealand faces. In 2012-13, these Challenges had a budget allocation of about $\$ 135$ million. Two key themes from Gluckman's report - growing future scientists and growing scientifically literate citizens - appear in several locations across the Challenges, and research proposals designed to address these issues have been invited. 
These are not, however, new issues. A great deal is already known, and the work commissioned via the National Science Challenges is likely to replicate this, rather than tell us anything new. Very briefly, according to the available research data, New Zealand is producing sufficient science graduates to meet our current needs, but, broadly speaking, most New Zealanders are not particularly welleducated in or well-disposed towards science. Student interest in science declines from mid-primary school level onwards, and many science-able students express little interest in pursuing careers in science. ${ }^{6}$ These are long-standing and continuing trends, and many other countries have similar patterns.

From the point of view of the policy goals outlined in Gluckman's paper, there is a problem. However, it is not a new problem: it is a problem that is already wellresearched by science education scholars, particularly at the school level. While most universities now work hard to develop their graduate profile/s, teaching methods, and equal opportunity, the point of this work is to recruit a wider range of people into "business-as-usual" science. While this may be a good thing, it does not address the problem identified in Gluckman's report. The expanded, innovation-oriented science sector he envisages requires a new kind of graduate, and producing these would require a system re-focus.

My point here is that we are not thinking hard enough about what is needed, either from the point of view of science, or from the point of view of education. The result of this, as I argue later, is that much of our current practice is, to use Dewey's term, actually mis-educative.

In 2011-12, the New Zealand Ministry of Education picked up on the issues identified in Gluckman's report, commissioning three large science education research projects. These were carried out in 2012-13. One project investigated the possibilities for e-learning in science, a second explored the connections between school science and scientists, and the third focused on developing resources for teachers. ${ }^{7}$ However, underpinning the design and the findings of these projects was the assumption that problems with school science are solvable with better teaching, and that this is best achieved by providing more resources for teachers, more exposure to "real science," and more opportunities for teachers to collaborate with expert scientists and with other teachers. This, it is thought, will make school science more "engaging" for young people, and more of them will choose to continue their study of science beyond the compulsory stage.

However, this work does not challenge current thinking about school science. It provides support for teaching science much as it has always been, albeit with improved "connectivity" and higher "production values" (via digital resources and e-learning). Our past assumptions about science's nature and purpose remain unchanged, as do past assumptions about science's purpose in the school curriculum. While this plays out differently in the different sectors of education, the deeper issue is the same: we assimilate the new ideas into our existing frameworks. There is no system re-focus, and things stay more or less the same. 
I want to argue here that the policy-oriented work outlined above is based on "old" thinking that will not produce the "forward-looking science education system" or the cadre of innovators Gluckman are hoping for (Gluckman, 2011, p. vi). From an educational point of view, it is unlikely to foster the kinds of intellectual and citizenship capabilities needed for full participation in the world of the future. But worse, because it actively reproduces the very ways of thinking that most need to change, it is likely to be harmful.

It seems to me that achieving a forward-looking science education system is a very long way off, as is the goal of a scientifically literate population. The gap between what school science education programmes offer and the needs or interests of young people is not new, but, because science capability is seen as crucial to economic progress, every few years we see a resurgence of claims for a "crisis" in science education (e.g. see Aubusson, 2013; Toscano, 2013). Each new crisis results in reports and research being commissioned, new teaching approaches being recommended, and new curricula coming into effect. But, while there may be small changes (e.g. new terms are used), basically things continue much as they always have. As DeBoer (1991) shows, in his history of school science over a century or more, this is a well-established pattern. The strategies outlined above are just one more chapter in a long history of attempts to reform science education, and they are not very different from past attempts. However, I want to argue that things need to be different this time. Doing more of the same is no longer enough, given the context we are now in.

In the next section of this article, I put forward four broad reasons why things need to be different. Two have to do with science and two are education-centred.

\section{Why "More of the Same" Is Not Enough}

\section{Reason 1: School science misrepresents science.}

Leaving aside the question of whether or not science, innovation and prosperity are linked, ${ }^{8}$ it is clear that today's science is very different from that of a generation ago. How science is done, how it is reported, who is doing it, what attributes they need, and how it is connected with innovation have all changed. And, related to this, there has been a shift in how people think about, represent, and use knowledge. School science has not kept up with these shifts. If this trend continues, I think we will see an increase in the rate of decline in interest in science. The outdated view of science that is often presented in school science reproduces ways of thinking that are not helpful in today's science; ${ }^{9}$ it turns away people with the qualities most needed in today's science professionals, ${ }^{10}$ and it is not helpful to the development of a scientifically literate public. The "ideas generators," "problemsolvers" and science-positive citizens that Gluckman (and others) say we need may come from today's schools, but, if they do, this will be despite, rather than as a result of, their school science experiences. So: what has changed? 


\section{"Post-Academic" science}

Scientific research has changed significantly over the last century or so. In the eighteenth and nineteenth centuries, scientific work was mostly done by individuals working on their own, pursuing their individual interests, usually in a non-professional capacity. In the twentieth century, this model was largely replaced by two parallel cultures: academic (university-based) scientists working alone or in small teams, largely following their own interests, and industrial scientists working in large teams on commercially driven projects. However, from the later twentieth century onwards, these two cultures came together into what Ziman (2000) calls "post-academic" science, largely as a result of changes to the funding of universities and other public science. Post-academic scientific work takes place in large teams, usually networked across several institutions and countries. The work involves a succession of projects that must be justified in advance in order to attract funding. The projects are usually large in scale, multi-disciplinary, and multimethod. They commonly deal with highly complex systems with many interconnecting effects. Some projects involve ethical issues, some will be of interest to local communities, some will be subject to business and political influence. The scientists working on the projects are expected to be able to communicate their findings to non-specialist audiences. ${ }^{11}$ However, increasingly something more than communication is required: the ability not just to "explain" or "make accessible" their work to less knowledgeable others, but to acknowledge, negotiate, and work collaboratively with other experts - from different areas of science, from outside science, and from the interested public.

The influence of "post-academic" science (what science now is, how it is done, and, importantly, the skills and knowledge it takes to be successful in it) is, in most cases, not yet evident in school science. Neither is the related body of scholarly work known as the "social studies of science," and built up over the last thirty years or more, on how scientists actually do science (as opposed to what, in theory, they say they do). ${ }^{12}$

More recent work discusses a new, more radical shift to what some commentators call "postnormal times" (e.g. Ravetz, 2011; Sardar, 2010; Slaughter, 2012). This term was first used in the 1990s to describe changes in science (e.g. Capra, 1996; Funtowicz \& Ravetz, 1993), in particular, the recognition that things can no longer be thought of as if they were certain, simple or stable. As Ziauddin Sardar puts it, uncertainty, complexity, chaos, and contradictions are the "new" normal. According to him:

We live in an in-between period where old orthodoxies are dying, new ones have yet to be born, and very few things seem to make sense. Ours is a transitional age, a time without the confidence that we can return to any past we have known and with no confidence in any path to a desirable attainable sustainable future. (Sardar, 2010, p. 435) 
In postnormality, everything is complex - that is, deeply entangled, interconnected, unpredictable, and open. Any problem has multiple dimensions: there can be no "right" or "wrong" answers, just different ways to understand the problem. "Reality" is incomprehensible via the traditional disciplines, which rely on reducing the system to a selection of discrete units, inevitably leaving out key aspects. According to Sardar (2010), in postnormal times, "business as usual" modes of thinking and behaving are "now dangerously obsolete": they are "an invitation to impending catastrophe" (p. 441).

If we accept this, then many of modernity's key concepts no longer apply. This is of course deeply challenging to traditional science, but it also challenges many of education's core assumptions.

\section{"Too big to know"?}

Alongside - and related to - the changes in science, there has been a shift in how knowledge in general is understood, a shift now widely known as the "knowledge age." This term began to appear in the late twentieth century, first to signify an economic shift. In the new "fast capitalism," knowledge was seen to be replacing tangible goods as a key driver of new economic growth (e.g. Drucker, 1993; Gee Hull \& Lankshear, 1996; Leadbeater, 2000a; 2000b; Neef, 1998; Peters, 2001; 2002; Stehr, 1994; Thurow, 1996). Alongside this, internet-related developments saw new knowledge being generated in huge volumes at ever-increasing speeds, and continuously updated by multiple contributors. The result of this, some commentators argue, has been a change in knowledge's meaning, new understandings of what knowledge is and how it is used. Knowledge is now widely seen, not as "stuff," but as something that does stuff. Rather than being something we have, knowledge is something we $d o$. According to Castells (2000), it is like a form of energy, or, as Barlow wrote two decades ago, knowledge is a verb now, not a noun (Barlow, 1994). It is no longer something that lives in the brains of experts, or in objects that contain it, like books or libraries. These are way too small. It lives - and is created and replaced - in the spaces between experts, books databases and so on. According to Weinberger (2011), it is no longer tenable to think of knowledge as a stable body of facts or truths, a "thing in itself." It is not masterable and it does not necessarily reflect the world. Knowledge now exists in, and is a property of, networks: it is networked expertise. Weinberger says that this does not mean that the network is knowledge, that the network creates meaning, or that it is some kind of conscious super-brain. It is not. Rather, the network enables connected groups to take ideas further and faster than any individual could. However, the knowledge they create is located, not in individual heads, but in the collaborative space.

\section{“Open"-Or post-post-academic science}

These developments have changed science. Science is taking on many of the properties of its new medium - the network. Like the network, science is now incomprehensibly huge. It is also more public, less hierarchical, less filtered, and 
more open to difference (Weinberger, 2011). More people, many of whom are nonexperts, are contributing, via the "crowdsourcing" of data (Cook, 2011) and/or "citizen science" (Peters, 2016). Data is "published" earlier: it is accessible and transparent to all, and is being discussed in interest groups while still in "unfinished" form. This new form of science, called Open Science by some commentators, and Science 2.0 by others, has new and different practices, and is producing new knowledge "ecologies" (Irwin, 2016). These new "collaborateearly" forms of science, according to these commentators, are highly productive (Peters \& Jandrić, 2015; Waldrop, 2008), ${ }^{13}$ and are now the main source of innovation in today's world (Peters, 2010; Peters \& Roberts, 2011; Weinberger, 2011). Doing this kind of science requires attributes that were not encouraged in the previous generation of scientists, and its development will be challenging for many in today's science workforce.

These developments are highly disruptive to most people's ideas about science, and their ideas about education. They also challenge many of the ideas behind current government science policy. Becoming a "smart" knowledge- and innovation-oriented country does not mean producing more "knowledgeable" people - more people who have been "filled up" with existing knowledge. It means having more people with a new and different orientation to knowledge, people who know enough to do things with knowledge, but who can also work productively with others: in other words, people who are innovation-capable. This brings us to the second of the four reasons I want to put forward for why school science needs to change if it is to be "forward-looking": the relationship between school science and innovation.

\section{Reason 2: School science does not foster innovation}

In the past, science and innovation were seen as clearly distinct activities. Science was the pure or applied "blue skies" kind of research that builds new, "public good" knowledge. Innovation, on the other hand, involved using that knowledge to create new technologies and processes. However, the advent of the new, more "open" forms of science outlined above has blurred this distinction, and it seems likely that science and innovation will become more connected than they were in the past. This raises questions that do not appear to have been considered in recent discussions of how best to build the "forward-looking science education system" envisaged in Gluckman's report. If science and innovation are now closely linked activities, what does that mean for the way science is portrayed to school students? What does it mean for the pedagogies that might be used? Should school science's role be expanded to include the fostering of students' innovation capabilities? Are innovation capabilities discipline-specific? Should students have a deep understanding of science before they are encouraged to use science to innovate? What connection should there be with the school technology curriculum? Is building students' innovation capabilities more appropriately located in the technology curriculum? And, importantly for the purposes of this article, if school 
science was reconfigured to build students' innovation capabilities alongside their knowledge of science, would this new approach be educative?

However we might want to answer these questions, the way our schools are currently configured is very definitely not designed to produce innovators. The table below paraphrases material in a recent book by Tony Wagner called Creating Innovators to compare the conditions needed for innovation with those found in most schools.

Table 1 Conditions for innovation (after Wagner, 2012)

\begin{tabular}{|l|l|}
\hline Conditions encouraging innovation & Conditions in most schools \\
\hline $\begin{array}{l}\text { Opportunities for thoughtful risk-taking, } \\
\text { trial and error, to explore, to push } \\
\text { boundaries. }\end{array}$ & $\begin{array}{l}\text { Risk avoidance, compliance, obedience to } \\
\text { authority, producing fast, "right" answers. }\end{array}$ \\
\hline $\begin{array}{l}\text { Opportunities to create, to actively produce } \\
\text { new things. }\end{array}$ & $\begin{array}{l}\text { Passive consumption of existing } \\
\text { knowledge. }\end{array}$ \\
\hline $\begin{array}{l}\text { Emphasis on multi-disciplinary learning - } \\
\text { STEAM = STEM + liberal arts together. }\end{array}$ & Specialisation - arts or sciences. \\
\hline $\begin{array}{l}\text { Intrinsic motivation - "passionate play with } \\
\text { a purpose". }\end{array}$ & $\begin{array}{l}\text { Extrinsic motivation - goal is to } \\
\text { "achieve" = scoring well on tests. }\end{array}$ \\
\hline $\begin{array}{l}\text { Difference and unconventionality are } \\
\text { valued. }\end{array}$ & $\begin{array}{l}\text { Standardisation - one size fits all, } \\
\text { "production line" model of learning. }\end{array}$ \\
\hline $\begin{array}{l}\text { Space to follow interests, and to develop } \\
\text { deep knowledge in those areas. }\end{array}$ & $\begin{array}{l}\text { Superficial knowledge, and as a result, } \\
\text { limited "real" (conceptual) understanding. }\end{array}$ \\
\hline $\begin{array}{l}\text { Opportunities to collaborate, to work with } \\
\text { others with different knowledge/expertise to to } \\
\text { solve problems that all participants care } \\
\text { about. }\end{array}$ & $\begin{array}{l}\text { Emphasis on individual effort and } \\
\text { "achievement", on individual learning of } \\
\text { pre-set, already existing knowledge. }\end{array}$ \\
\hline
\end{tabular}

I think this table speaks for itself. All I will say here, to summarise so far, is that if we think it is important to engage more young people in science, to foster the dispositions required in the science professionals of today's world, and to foster the development of our future innovators, then doing more of what we do now, even if we were to do it much better, is very definitely not enough. I now turn to two more educationally-oriented reasons why current practice is not an adequate basis for building a "forward-looking" science education system.

\section{Reason 3: School science is not "future-focused"}

The last decade and a half has seen a proliferation of research and commentary on education's future. References to "future-focused" education, " $21^{\text {st }}$ century learners," "digital natives," and so on are now routine, particularly in policy contexts. This literature, broadly speaking, argues that today's schools are not adequately preparing young people for the increasingly complex, uncertain, and fast-changing world of the future, and the need for change in education is now urgent (e.g. Beare, 2001; Christensen et al., 2008; Gilbert, 2005; Khan, 2012; 
Leadbeater, 2011; Miller et al., 2008; Miller \& Bentley, 2003; Murgatroyd, 2011; Prensky, 2001; Robinson, 2011; Tuomi \& Miller, 2011; Wagner, 2008; 2012).

This literature is eclectic: it draws on ideas from many sources, often outside education, for a range of very different purposes. Pulling together its common elements produces a two-part story. Part one describes the "paradigm shift" taking place in the world beyond education and lists some of the "mega-trends" driving it. This list usually includes the following. First is the "digital revolution" - the exponential growth in computing power and digital networks, and the implications of this for society, the economy and the nature and distribution of employment opportunities (see Kurzweil, 2005; Brynjolfsson \& McAfee, 2011). Second is globalisation - the dissolving of boundaries between nation-states and their economies. Third is the development of new, "networked" forms of knowledge that are now "too big to know" (Castells, 2000; Weinberger, 2011). Fourth is the projected shift in world order that is likely to result from the demographic and economic changes now well under way in, for example, the BRICS group of countries $^{14}$ (Marginson et al., 2011). The fifth mega-trend encompasses the developments linked to the Anthropocene - climate change and the many other "wicked problems" we face in the twenty-first century. ${ }^{15}$ These five trends, it is argued, will produce the end of work as we currently know it. Most manufacturing work, as well as whole classes of professional work, including scientific work, will be replaced by intelligent technologies (e.g. Brynjolfsson \& McAfee, 2011; Susskind \& Susskind, 2015; Dunlop, 2016). The breakdown of nation-state boundaries will limit the ability to levy taxes, which will in turn limit the capacity to provide public services, invest in infrastructure, and so on. Social inequalities will increase. And then there are the physical effects of climate change.

Taken together, these trends represent a strong challenge to the current order, and to "known" ways of doing things. However, the response, in most "first world" countries, has been to strive to maintain competitive advantage, to mitigate the risk of economic and/or political oblivion. This is where, in this story, education comes into the picture. In Part two of the future-focused education story, schools are portrayed as having failed to respond to these trends, as being inert, outdated, obsolete, and no longer "fit for purpose." Part of another age, they rely on, and are embedded in, "old knowledge," "old systems," and "old technologies." We need, the argument goes, to "revolutionise" education, rebuild it from the ground up, so it can better meet the needs of these "new times."

However, while this story is now well-known and pervasive, it has not produced a revolution in educational thinking. Schools continue to be organised by the same knowledge, the same systems, and, to a large extent, the same technologies (in the widest sense of this term). In the policy rhetoric on education's future, two "big ideas" predominate. The first is better system performance - a future-focused system is one that produces higher rates of student achievement, and more students with tertiary qualifications. The second is digitisation - e-learning and better data management. However, these ideas are a finessing of "old" understandings of 
education, not a framework for preparing young people to live, think, and act in tomorrow's world.

A few educational theorists have grappled with the deeper implications for education of the new times (e.g. Facer, 2012; 2013; Gough, 1990; Milojevic, 2005; Morgan, 2013). Some, most notably Richard Slaughter, Noel Gough, and William Doll, have been working in this area for twenty years or more. Some of their work deals with science education's future - in particular, its possible role in our longterm social development and the future of the planet. For example, Slaughter (2012), in making a case for why science educators routinely do not engage in futures thinking, shows how science and technology are routinely depicted as the future: that is, the idea that the future will be "built" via advances in nanotechnology, biotechnology, IT and so on, and that science will "save" us from the problems we face. This is twentieth century thinking. As Slaughter points out, science and technology do not, by themselves, shape the future: it is shaped by prior human choices about the values used to create and guide developments in science and technology (Slaughter, 2012). Similarly, science education's future will be shaped by human choices and values, by the ideas we collectively have now about the kind of future we want to create, and about the role science should play in that.

\section{Reason 4: School science is not "educative"}

Discussions of "future-focused" education have so far paid little attention to the question of education's aims and ends. What is education for in the twenty-first century? Are its purposes more or less the same as in past times, or is something new required? What does it mean to be an educated person in the twenty-first century?

These questions have of course been central to the work of some educational philosophers. For example, John Dewey, in Experience and Education (1938), argues that "educative" experiences are those that open up possibilities for active growth, via further and deeper experiences. Experiences are important, but not as ends in themselves. Rather they are a context for, as he puts it, the

progressive development of what is already experienced into a fuller and richer and also more organised form, a form that gradually approximates that in which the subject-matter is presented to the skilled, mature person. (pp. 73-4)

For Dewey, education involves scaffolding the development of intellectual adulthood. It involves a slow and steady apprenticeship into adult-like ways of thinking and forms of knowledge. It involves learning to think for oneself, in increasingly abstract and complex ways. According to Dewey, an experience is "mis-educative" if it "has the effect of arresting or distorting the growth of further experience" (p. 25), that is, if it constrains or arrests a person's intellectual development. Making sense of one's experiences, in order to build on them, 
requires active intellectual engagement, active processing of ideas in the context of one's experiences.

Alfred North Whitehead, another early twentieth century philosopher, emphasises the role of ideas in intellectual development and what it means to be educated. In his 1929 book The Aims of Education and Other Essays, he characterises education's purpose as being to build "activity of thought" by working with ideas. He argues that

above all things we must beware of what I will call "inert ideas" - that is to say, ideas that are merely received into the mind without being utilised, or tested, or thrown into fresh combinations. (p. 1)

Being educated, for Whitehead, involves using, playing with, and appreciating ideas, and, importantly, the relationships ideas have with other ideas. Ideas are not inert, static entities to be passively acquired and stored away - they are complex, organic and malleable, always in process. According to Whitehead:

What education has to impart is an intimate sense for the power of ideas, for the beauty of ideas, and for the structure of ideas ... [Education should develop an] eye for the whole chessboard, for the bearing of one set of ideas on another. (p. 8)

Education with inert ideas is not only useless, it is, above all things, harmful - Corruptio optimi, pessima. (p. 1)

For Dewey and Whitehead then, education's purpose is intellectual development. It involves expanding people's capacity to actively work with - and improve - ideas, at ever-increasing levels of complexity and abstraction.

If we accept this, then forms of science education that aim to fill students up with knowledge about science are mis-educative. They are not useful, they do not build intellectual capacity, and they are potentially harmful. This contention is not new in the science education literature. My point in this article is that this issue, and the need to face up to it in policy contexts, is becoming increasingly pressing for the future of science, and for the future of education.

Following Dewey and Whitehead's views of education's purpose, the extent to which school science has ever been educative is debatable, but now, as science itself becomes increasingly networked, open, and conflated with innovation, school science is less and less "fit for purpose." Unless we want to see a rapid acceleration in science education's already well-established decline ${ }^{16}$ we need to break out of the automated thinking ${ }^{17}$ outlined earlier in this article. To do this, I think it is helpful (and hence the title of this article) to go back to some older ideas about education's purpose, with a view to "re-purposing" them for the new times we are now in. In particular, it seems to me, the concept of intellectual development could be re-purposed. Drawing on Dewey and Whitehead, intellectual development in the twenty-first century could mean expanding people's capacity to actively work with increasingly abstract ideas, but with the aim of preparing them, not to contribute 
new knowledge to the existing disciplines, but to work across the disciplines, to work in/with complexity, change, difference, and multiplicity. If we think it is important to resist the currently prevailing view of education as little more than "content delivery," if we think it is important to keep alive the debate around education's purpose, then perhaps we need a discussion of how we might $d o$ intellectual development differently in the twenty-first century.

\section{Imagining Possible Future/s for Science Education}

Can science education's aims and ends be re-imagined to address the issues outlined above?

In the final section of this article, I suggest three different possible pathways for science education's future, and look briefly at the implications of each for our collective future/s. These pathways are not intended as predictions and they obviously simplify some highly complex issues. Their purpose is just to serve as a starting point for the debate about science education's future aims and ends that, in my view, we urgently need to have.

\section{Pathway 1: "More of the same"}

Science education continues to see itself as having two main purposes: providing pre-professional training for the scientists of the future, who, it is assumed, will be working in ways familiar to twentieth century scientists, and producing citizens who are "literate" in science and well-disposed towards it. The focus of educators and policy-makers is on continuous improvement, seeking ever more efficient ways of achieving these purposes.

School science keeps its traditionally strong disciplinary boundaries (Bernstein, 1971) and continues to explore ways to make itself more "relevant" and/or "engaging" to students. New, more appealing "content" (e.g. socio-scientific issues) is added, and new pedagogies are developed. Discussion of the importance of scientific skills, "capabilities," or "competencies" continues, largely apart from the "content" debates, and the pedagogical connections between the "knowing," "doing" and "thinking" aspects of science remain under-theorised.

Debate about why so many students are not particularly positive about school science and/or a career in science continues, much as it always has. Science education research increasingly focuses on "teacher effects" - improving teachers' content knowledge, their pedagogical knowledge, and their pedagogical content knowledge, via new and improved pre-service teacher education and in-service professional learning programmes. School-scientist collaborations are a focus, and are allocated increasing funding support. Science education teacher professional learning is designed to "bridge gaps" in teachers' science knowledge, provide access to up-to-date technologies, and provide authentic science experiences for students. Investment in "e-learning," both as a tool for communication/ collaboration and a way of providing simulated and/or authentic science 
experiences, increases hugely, to the extent that it forms a major new niche industry. Because science continues to be seen as central to future economic prosperity, there is an increased investment in science education, but, despite this, its content, its purposes and its pedagogies continue to look very much as they always have.

Intellectual development continues to be, at least in theory, an aim of science education, but very much in the background, as it is now, something that can be expected to happen "naturally" as learners are exposed to traditional disciplinary knowledge.

\section{Pathway 2: "Science as innovation"}

The early twenty-first century policy focus on innovation's role in economic prosperity produces major changes in science education. Science and innovation (traditionally distinguished), are seen as strongly linked, and science/innovation is central to economic growth. Science is now valued, not as an end in itself, but for its "performativity," what can be done with it (Lyotard, 1984). This shift was a response to perceived economic imperatives; however, it was also based on an acknowledgement of the major changes to science that took place in the later twentieth century (the "post-academic," "open" and "networked" forms of science described earlier in this article).

These changes, together with the policy emphasis on innovation, produce calls for change in school science. Initially, these involve an emphasis on collaborative work, "e-learning," and students participating in "authentic" science (e.g. bird counts, collecting weather or water quality data). But later, picking up on research on the conditions needed for innovation (e.g. Wagner, 2012), science educators begin to advocate approaches designed to develop the "diversive" forms of curiosity found in very young children into the deeper, more disciplined, "epistemic" forms of curiosity that underpin mature intellectual development (Leslie, 2014). Using Scardamalia \& Bereiter's (2006) concept of "knowledgebuilding," there is a focus on working with ideas, building deep knowledge in specific areas, collaborating with others with different expertise, and using this knowledge in creative endeavours.

This pathway allows intellectual development to be re-purposed for new times. Resources are available to support this: for example, Scardamalia \& Bereiter's "knowledge-building" work aims to develop Knowledge Age pedagogies: in essence, "knowledge-building" means working with - and "improving" increasingly abstract ideas, in collaboration with others.

But, for this idea to be taken up productively (in policy and practice contexts), there would first need to be deep engagement with the new forms of science - the new practices, but also the epistemological implications of these new practices, and, following from this, the implications - and likely new purposes - for science education. For example: should science education's primary purpose be to turn out "work-ready" innovators, as this is currently defined: that is, people who have 
ideas (that draw on and use deep understanding of existing knowledge), and who can work with ideas, in collaboration with very different others? Should science education's purpose be to turn out people who are "innovation-literate," people who know about innovation, who have some "innovation skills," and who are welldisposed toward innovation? Would this still be science education? To what extent would this be "educative," in the sense meant by Dewey?

If policymakers and practitioners do not engage with these questions, we are likely to see talk of collaboration, communication, networking, critical thinking, and so on, and possibly the development of some apparently new practices, but, in the end, probably nothing that is actually new. Without new thinking about science education's deeper purposes, these concepts, like so many others before them (e.g. enquiry, capabilities, nature of science, socio-scientific issues, and so on), will not revolutionise science education, but will simply became more "stuff to know" for students.

\section{Pathway 3: "Postnormal" science education}

Widespread acceptance of the increasing likelihood of abrupt climate change ${ }^{18}$ influences science education policy and practice. Discussion of new purposes for science education in the twenty-first century is informed by work on the qualities needed to survive and thrive in "postnormal" times: for example, Sardar (2010) and Cilliers (2005) focus on imagination, creativity and ethical thinking, while Csikszentmihalyi (1996) and Johnson (2014) emphasise resilience, persistence, the capacity to hold multiple perspectives simultaneously, and the ability to shift between openness and discipline. There is robust discussion of the implications of the deep links science (and science education) have with the "carboniferous capitalism" (Newell \& Patterson, 2010) that is largely responsible for humaninduced climate change.

Out of all this, new forms of science education emerge that aim to build the intellectual capacities - individual and collective - needed in postnormal times. Informed by complexity thinking (e.g. Byrne \& Callaghan, 2014; Cilliers, 1998; Miller \& Page, 2007; Mason, 2008; Osberg \& Biesta, 2010), scientific knowledge is represented, not as discrete bits of knowledge to be mastered in sequence, but as a highly complex, always-changing system of inter-connected elements that are fundamentally unmasterable (Capra, 2002; Capra \& Luisi, 2014). Education's aim is no longer to ensure the acquisition of already-existing bits of knowledge; rather, it is concerned with how that knowledge is engaged with and responded to, and with what emerges from that engagement. Instead of focusing on replicating and stabilising existing worlds, its aim is to foster the conditions from which new worlds can emerge (Biesta, 2006; Osberg, 2005; Osberg, Biesta and Cilliers, 2008).

These three broad pathways have been deliberately overstated, with little overlap, as a kind of heuristic designed to provoke the discussion that, I think, we need to have if science education is to have a future. It is of course highly unlikely that we will follow any one of these pathways. Rather, what we are likely to see is 
a process in which elements from each are selected and "recontextualised" (Bernstein, 2000) to fit with broader external power relations.

\section{Conclusion}

My purpose in this article has been to question current policy on science education, to argue that current policy, because it draws on outdated views of science and education, is effectively arresting our collective future intellectual development, and, following from this, that it is mis-educative, and probably harmful.

What could science education that is both "future-focused" and "educative" look like? What should its purpose be in the twenty-first century? As a starting point for discussion, I suggest that it might have some of the following features:

- It would aim to build learners' understanding of science while at the same time building their capacity to do things with these understandings.

- It would aim to foster the dispositions and skills needed in scientific work - e.g. critical thinking; the capacity for abstraction; the capacity to work with complexity, uncertainty and ambiguity; the capacity to hold multiple perspectives simultaneously; the ability to work with others to improve ideas; and facility in communication, argumentation and debate.

- It would encourage experimentation and play, not in a contrived way, to "get the right answers," but to develop intellectual capacity.

- It would encourage students to develop and follow their own interests, at increasing levels of complexity, where necessary, supported through external collaborations and resources.

- It would encourage difference, risk-taking and unconventional thinking. Its aim would be not to reproduce existing thinking but to develop the conditions for new thinking.

Its primary goal would be intellectual expansion, developing the capacity for active independent and collaborative thought, in situations of increasing complexity and abstraction. These aims are of course not very different from those advocated by Dewey and Whitehead, almost a century ago.

Over the century and a half of science education's formal existence, many of its scholars have grappled with these questions, and some are continuing this work now. For example, in the New Zealand context, recent work has focused on specifying certain science "capabilities," many of which could - and were probably intended to - fit into the list above. ${ }^{19}$ However, in practice, these capabilities have been added into, or "over-assimilated" to the existing framework, becoming yet another thing to be learned "about." 20 They have not produced the "system re-set" that I argue in this article is needed if we are to build a genuinely "forwardlooking" science education system. This is a familiar pattern in science education's history (DeBoer, 1991), which should tell us something. In my view, it tells us that 
"the problem" that is the focus of this article does not lie with ideas that are espoused at the "surface" of these debates. Rather, it is located in a much deeper, more inaccessible place - inside each of us, and our largely taken-for-granted assumptions about science, about education (and its purposes), and, following from this, science education's purposes. The point of this article has been to argue that, as we move into increasingly complex, uncertain, "postnormal" times, our old, taken-for-granted ideas just are not up to it any more. However, the large unanswered question here is the one that has to do with how we might go about producing the required shift in thinking.

\section{NOTES}

1. This wording appeared on the MSI website http://www.msi/govt.nz at the time of the Ministry's establishment.

2. This wording was taken from the MSI website in 2012 as the transition to MBIE was in progress.

3. The former Department of Scientific and Industrial Research (DSIR), New Zealand's organisation for government science, set up in 1926, was disestablished in 1992.

4. See http://www.mbie.govt.nz/info-services/science-innovation.

5. See: htttp://www.mbie.govt.nz/info-services/science-innovation/curious-minds.

6. See: Caygill (2008a, 2008b), Crooks et al (2008), OECD (2009), Hipkins et al (2006), Telford (2010), Tytler (2007), Wylie \& Hipkins (2006).

7. For details of these projects, see: Bolstad \& Bull et al. (2013), Buntting \& Bolstad (2013). The focus of the third of the three projects was on developing what are now known as the science "capabilities." These were intended to support teachers to "join the dots" between various key strands of New Zealand's official curriculum document. See: Hipkins (2014). I should acknowledge that I participated in the three projects outlined above.

8. There is a well-developed critique of this model of science and innovation. See, for example, Mirowski (2011).

9. See Hodson $(2003 ; 2011)$ or Gilbert (2005) for an elaboration of this argument.

10. See Tytler (2007) for a review of the evidence for this.

11. One result of this is the recent development of new papers and/or whole programmes on "science communication" in our universities.

12. The social studies of science is a huge field. For some of the best-known early ethnographic studies of scientists' work see: Knorr-Cetina (1981; 1999); Latour (1987; 1993); Latour \& Woolgar (1979); and Traweek (1988; 1989). For an accessible summary of this body of work, see Sardar (2002).

13. See also: the OpenWetWare project at MIT www.openwetware.org, or the Science Commons project www.science commons.org.

14. BRICS refers to Brazil, Russia, India, China and South Africa.

15. The term "wicked problem" is now widely used to refer to very complex problems that are difficult or impossible to solve - or even define - using the tools and techniques of one organisation or discipline. Because they have multiple causes and complex interdependencies, efforts to solve one aspect of a wicked problem often reveal or create other problems. See Conklin (2006).

16. See note 6 above. 
17. This term comes from Kahneman (2011). In his book Thinking Fast and Slow, he argues that we are "hard wired" to automate our thinking, because it takes considerably less energy.

18. "Abrupt" climate change is change that is so rapid that humans and other natural systems do not have time to adapt to it (IPCC, 2014). According to some commentators, we can expect this to occur within 20 years.

19. See, for example, Hipkins \& McDowell (2013).

20. See Bull (2015); Hipkins \& McDowell (2013).

\section{REFERENCES}

Aubusson, P. (2013). Science education futures - Unchaining the beast. Briefing paper prepared for the Monash University seminar on Science Education Futures in 2020 2025, 19 February. Melbourne, Australia: Monash University.

Barlow, J. (1994). The economy of ideas. Wired 2.03.

Beare, H. (2001). Creating the future school. London, England: Routledge.

Bernstein, B. (1971). On the classification and framing of educational knowledge. In: M. Young (ed.), Knowledge and Control: New Directions in the Sociology of Education. (pp. 47-69). London, England: Collier Macmillan.

Bernstein, B. (2000). Pedagogy, symbolic control and identity. Lanham, MD: Rowman \& Littlefield.

Biesta, G. (2006). Beyond learning: Democratic education for a human future. Boulder, CO: Paradigm.

Bolstad, R. \& Bull, A., with S. Carson, J. Gilbert, W. MacIntyre, \& L. Spiller (2013). Strengthening engagements between schools and the science community: Final report. Retrieved from New Zealand Council for Educational Research: www.nzcer.org.nz/ research/publications/strengthening-engagements-between-schools-and-sciencecommunity

Brynjolfsson, E. \& McAfee, A. (2011). Race against the machine: How the digital revolution is accelerating innovation, driving productivity and irreversibly transforming employment and the economy. Lexington, MA: Digital Frontier Press.

Bull, A. (2015). Capabilities for living and life-long learning: What's science got to do with it? Wellington, New Zealand: New Zealand Council for Educational Research. Retrieved from http://www.nzcer.org.nz/system/files/Capabilities\%20for\%20living\% 20and\%20lifelong\%20learning\%28v2\%29.pdf.

Buntting, C. \& Bolstad, R. (2013). E-in-science: Future-oriented science learning. Retrieved from New Zealand Council for Educational Research: http://www.nzcer.org. nz/research/publications/e-science-future-oriented-science-learning.

Byrne, D. \& Callaghan, G. (2014). Complexity theory and the social sciences. The state of the art. London, England: Routledge.

Capra, F. (2002). The hidden connections. New York, NY: Anchor.

Capra, F. (1996). The web of life: A new scientific understanding of living systems. New York, NY: Anchor.

Capra, F. \& Luisi, P. (2014). The systems view of life: A unifying vision. Cambridge, England: Cambridge University Press.

Castells, M. (2000). The rise of the network society. (2 ${ }^{\text {nd }}$ edn.) Oxford, England: Blackwell. 
Caygill, R. (2008a). Science: Trends in Year 5 science achievement 1994 to 2006. Wellington, New Zealand: Ministry of Education.

Caygill, R. (2008b). PISA 2006: Student attitudes to and engagement with science. Wellington, New Zealand: Ministry of Education.

Christensen, C., Johnson, C. \& Horn, M. (2008). Disrupting class: How disruptive innovation will change the way the world learns. New York, NY: McGraw-Hill.

Cilliers, P. (1998). Complexity and postmodernism: Understanding complex systems. London, England: Routledge.

Cilliers, P. (2005). Complexity, deconstruction and relativism. Theory, Culture and Society, $22,255-267$.

Conklin, J. (2006). Dialogue mapping: building shared understanding of wicked problems. Chichester, England: Wiley.

Cook, G. (2011). How crowdsourcing is changing science. The Boston Globe, November 2011. Available at www.bostonglobe.com/ideas/2011/11/11/how-crowdsourcingis-changing-science.

Crooks, T., Smith, J. \& Flockton, L. (2008). Science assessment results 2007: NEMP Report 44. Wellington, New Zealand: Ministry of Education.

Csikszentmihalyi, M (1996). Creativity: The psychology of discovery and invention. New York, NY: HarperCollins.

DeBoer, G. (1991). A history of ideas in science education: Implications for practice. New York, NY: Teachers College Press.

Dewey, J. (1938). Experience and education. New York, NY: Collier MacMillan.

Drucker, P. (1993). Post-capitalist society. New York, NY: HarperBusiness.

Dunlop, T. (2016). Why the future is workless. Sydney, Australia: University of New South Wales Press.

Facer, K. (2012). Learning futures: Education, technology and social change. London, England: Routledge.

Facer, K. (2013). The problem of the future and the possibilities of the present in education research. International Journal of Educational Research, 61, 135-143.

Funtowicz, S. \& Ravetz, J. (1993). Science for the post-normal age. Futures, September 1993, 739-755.

Gee, J-P., Hull, G. \& Lankshear, C. (1996). The new work order: Behind the language of the new capitalism. Sydney, Australia: Allen and Unwin.

Gilbert, J. (2005). Catching the knowledge wave? The knowledge society and the future of education. Wellington, New Zealand: NZCER Press.

Gluckman, P. (2011). Looking ahead: Science education for the twenty-first century. A report from the Prime Minister's Chief Science Advisor. Auckland, New Zealand: Office of the Prime Minister's Science Advisory Committee. Available at: http:// www.pmcsa.org.nz/wp-content/uploads/Looking-ahead-Science-education-for-thetwenty-first-century.pdf.

Gough, N. (1990). Futures in Australian education: Tacit, token and taken for granted. Futures, 22, 208-310.

Hipkins, R. (2014). Unlocking the idea of "capabilities" in science. New Zealand Science Teacher. July 2014.http://www.nzscienceteacher.co.nz/curriculum-literacy/keycompetencies-capabilities/unlocking-the-idea-of-capabilities-in-science/\%23.WMnkbvl 97IU\#.WMnupRKGOi4.

Hipkins, R. \& McDowell, S. (2013). Teaching for present and future competency: A productive focus for professional learning. Teachers and Curriculum, 13, 1-10. 
Hipkins, R., Roberts, J., Bolstad, R. \& Ferral, H. (2006). Staying in science 2: Transition to tertiary study from the perspectives of New Zealand Year 13 science students. Research carried out for the Ministry of Research, Science and Technology. Wellington, New Zealand: NZCER. Retrieved from http://www.educationcounts.govt.nz/publications/ series/2303.

Hodson, D. (2003). Time for action: Science education for an alternative future. International Journal of Science Education, 25, 645-670.

Hodson, D. (2011). Looking to the future: Building a curriculum for social activism. Rotterdam, Netherlands: Sense Publishers.

Inter-Governmental Panel on Climate Change (IPCC) (2014). Climate change 2014: Impacts, adaptation and vulnerability: The fifth assessment report of the IPCC. Approved summary for policymakers. 1 November 2014. Retrieved from http://www. ipcc.ch/pdf/assessment-report/ar5/wg2/ar5_wgII_spm_en.pdf.

Irwin, R. (2016). Knowledge ecologies and education. Theme for the 2016 conference of the Philosophy of Education Society of Australasia. Retrieved from https://pesa.org.au/ conference/knowledge-ecologies-and-education

Johnson, B. (2014). Polarity management: Identifying and managing unsolvable problems. Amherst, MA: HRD Press.

Kahneman, D. (2011). Thinking fast and slow. New York, NY: Farrar, Straus and Giroux.

Khan, S. (2012). The one world school house: Education reimagined. London, England: Hodder.

Knorr-Cetina, K. (1981). The manufacture of knowledge. Oxford, England: Pergamon.

Knorr-Cetina, K. (1999). Epistemic cultures: How the sciences make knowledge. Cambridge, MA: Harvard University Press.

Kurzweil, R. (2005). The singularity is near. New York, NY: Viking.

Latour, B. (1987). Science in action: How to follow scientists and engineers through society. Cambridge, MA: Harvard University Press.

Latour, B. (1993). We have never been modern. Hemel Hempstead, England: Harvester Wheatsheaf.

Latour, B. \& Woolgar, S. (1979). Laboratory life: The social construction of scientific facts. London, England: Sage.

Leadbeater, C. (2000a). The weightless society. New York, NY: Texere.

Leadbeater, C. (2000b). Living on thin air: The new economy. Harmondsworth, England: Penguin.

Leadbeater, C. (2011). Rethinking innovation in education: Opening up the debate. Melbourne, Australia: Centre for Strategic Education.

Leslie, I. (2014). Curious: The desire to know and why your future depends on it. New York, NY: Basic Books.

Lyotard, J-F. (1984). The postmodern condition: A report on knowledge. Manchester, England: Manchester University Press.

Marginson, S., Kaur, S. \& Sawir, E. (eds.) (2011). Higher education in the Asia-Pacific: Strategic responses to globalization. Dordrecht, Netherlands: Springer.

Mason, M. (ed.) (2008). Complexity theory and the philosophy of education. Chichester, England: Wiley-Blackwell.

Miller, J. \& Page, S. (2007). Complex adaptive systems: An introduction to computational models of social life. Princeton, NJ: Princeton University Press.

Miller, R. \& Bentley, T. (2003). Unique creation: Possible futures - Four scenarios For $21^{\text {st }}$ century schooling. Nottingham, England: National College for School Leadership. 
Miller, R., Shapiro, H. \& Hilding-Harmann, K. (2008). School's over: Learning spaces in Europe in 2020: An imagining exercise on the future of learning. Luxembourg: European Commission.

Milojevic, I. (2005). Educational futures: Dominant and contesting visions. London, England: Routledge.

Mirowski, P. (2011). ScienceMart: Privatising American science. Cambridge, MA: Harvard University Press.

Morgan, J. (2013). The management of ignorance? The 'future-focus' and New Zealand social science teaching. New Zealand Journal of Educational Studies, 48, 19-33.

Murgatroyd, S. (2011). Re-thinking education: Learning and the new Renaissance. Edmonton, Canada: Future Think Press.

Neef, D. (1998). The knowledge economy. Boston, MA: Butterworth Heinemann.

Newell, P. \& Patterson, M. (2010). Climate capitalism: Global warming and the transformation of the global economy. Cambridge, England: Cambridge University Press.

OECD (2009). Top of the class: High performers in science in PISA 2006. http://www. oecd.org/dataoecd/44/17/42645389.pdf.

Osberg, D. (2005). Redescribing 'education' in complex terms. Complicity: An International Journal of Complexity and Education, 2(1), 81-83.

Osberg, D., Biesta, G. \& Cilliers, P. (2008). From representation to emergence: Complexity's challenge to the epistemology of schooling. Educational Philosophy and Theory, 40, 213-227.

Osberg, D. \& Biesta, G. (eds.) (2010). Complexity theory and the politics of education. Rotterdam, Netherlands: Sense Publishers.

Peters, M. (2001). National education policy constructions of the 'knowledge economy': Towards a critique. Journal of Educational Enquiry, 2, 1-22.

Peters, M. (2002). Education policy research and the global knowledge economy. Educational Philosophy and Theory, 34(1), 91-102.

Peters, M. (2010). Openness, Web 2.0 technology, and open science. Policy Futures in Education, 8, 567-574. DOI:/10.2304/pfie.2010.8.5.567

Peters, M. (2016). An inventory of citizen science initiatives, resources and learning opportunities in new zealand. Hamilton, New Zealand: NZ Landcare Trust.

Peters, M. \& Jandrić, P. (2015). Philosophy of education in the age of digital reason. Review of Contemporary Philosophy, 14, 162-181.

Peters, M. \& Roberts, P. (2011). The virtues of openness: education and scholarship in a digital age. Boulder, CO: Paradigm Press.

Prensky, M. (2001). Digital natives, digital immigrants. From On The Horizon. MCB University Press 9(5). Retreived from www.marcprensky.com/writing/Prensky.

Ravetz, J. (2011). Post-normal science and the maturing of the structural contradictions of modern European science. Futures, 43, 142-148.

Robinson, K. (2011). Out of our minds: Learning to be creative. ( $2^{\text {nd }}$ edn.). Chichester, England: Capstone.

Sardar, Z. (2002). Thomas Kuhn and the science wars. In: R. Appignanesi (ed.), Postmodernism and Big Science (pp. 87-233). Cambridge, England: Icon Books.

Sardar, Z. (2010). Welcome to postnormal times. Futures, 42, 435-444.

Scardamalia, M. \& Bereiter, C. (2006). Knowledge building: Theory, pedagogy, and technology. In: K. Sawyer (Ed.), Cambridge Handbook of the Learning Sciences (pp. 97-118). New York, NY: Cambridge University Press.

Slaughter, R. (2012). Welcome to the Anthropocene. Futures, 44, 119-126. 
Stehr, N. (1994). Knowledge societies. London, England: Sage.

Susskind, R. \& Susskind, D. (2015). The future of the professions: How technology will transform the work of human experts. Oxford, England: Oxford University Press.

Telford, M. (2010). PISA 2006: Scientific literacy: How ready are our 15 year olds for tomorrow's world? Wellington, New Zealand: Ministry of Education.

Thurow, L. (1996). The future of capitalism: How today's economic forces will shape tomorrow's world. New York, NY: William Morrow.

Toscano. M. (2013). Is there a crisis in science education? Paper presented to the Annual Conference of the Philosophy of Education Society of Great Britain, 22-24 March. Oxford, England: New College.

Traweek, S. (1988). Beamtimes and lifetimes: The world of high-energy physics. Cambridge, MA: Harvard University Press.

Traweek, S. (1989). Particle physics culture. Cambridge, MA: Harvard University Press.

Tuomi, I. \& Miller, R. (2011). Learning and education after the industrial age. Retrieved from http://www.rielmiller.com/papers/EK\%20v0.99\%20Learning\%20and\%20Education $\% 20$ After\%20the\%20Industrial\%20Age.doc

Tytler, R. (2007). Re-imagining science education: Engaging students in science for Australia's future. Camberwell, Australia: Australian Council for Educational Research.

Wagner, T. (2008). The global achievement gap: Why even our best schools don't teach the new survival skills our children need, and what we can do about it. New York, NY: Basic Books.

Wagner, T. (2012). Creating innovators: The making of young people who will change the world. New York, NY: Scribner.

Waldrop, M. (2008). Science 2.0: Is open access science the future? Scientific American, May 2008. Retrieved from http://www.scientificamerican.com/article.cfm?id=science2-point-0.

Weinberger, D. (2011). Too big to know: Rethinking knowledge now that the facts aren't the facts, experts are everywhere, and the smartest person in the room is the room. New York, NY: Basic Books.

Whitehead, A. N. (1929). The aims of education and other essays. New York, NY: The Free Press.

Wylie, C. \& Hipkins, R. (2006). Growing independence: Competent Learners @ 14. Wellington, New Zealand: New Zealand Council for Educational Research.

Ziman, J. (2000). Real science: What it is and what it means. New York, NY: Cambridge University Press.

Jane Gilbert is Professor of Education at Auckland University of Technology in New Zealand. Previously she was Chief Researcher at the New Zealand Council for Educational Research (NZCER). She has also worked in the Schools of Education at Victoria University of Wellington and the University of Waikato. Many years ago she was a secondary school science teacher. Jane's early academic work was in science/technology education and equity issues in education, but in the last 10-15 years she has mainly worked on questions connected with educational futures, focusing in particular on the implications of Knowledge/Network Age developments for educational thinking. 